http://jmscr.igmpublication.org/home/ ISSN (e)-2347-176x ISSN (p) 2455-0450 crossref DOI: https://dx.doi.org/10.18535/jmscr/v7i7.169

Journal Of Medical Science And Clinical Research

\title{
Flapless modified Toti's procedure with use of circumosteal Mitomycin C as an adjunctive therapy in management of failed Dacryocystorhinostomy (DCR)
}

\author{
Authors \\ Dr Nilesh Mohan MD (AIIMS), DNB, ICO (Basic Ophtha) ${ }^{1}$, Dr Gyan Bhaskar MS ${ }^{2}$ \\ Dr Bibhuti P Sinha $\mathrm{MS}^{3^{*}}$, Dr Ankita Kumari $\mathbf{M S}^{4}$ \\ ${ }^{1}$ Additional Professor, RIO, IGIMS, Sheikhpura, Patna \\ ${ }^{2}$ Additional Professor, RIO, IGIMS, Sheikhpura, Patna \\ ${ }^{3}$ Professor \& HOD, RIO, IGIMS, Sheikhpura, Patna \\ ${ }^{4}$ Senior Resident, RIO, IGIMS, Sheikhpura, Patna \\ *Corresponding Author \\ Dr Bibhuti P Sinha MS \\ Professor \& HOD, RIO, IGIMS, Sheikhpura, Patna, India
}

\section{Abstract}

Aim: A Prospective study of patients to assess the success rate of repeat DCR surgery by flapless modified Toti's rhinostomy with intraoperative use of Mitomycin C and syringing with $1 \mathrm{ml}$ of $0.2 \mathrm{mg} / \mathrm{ml}$ Mitomycin $C$ on first postoperative day in newly formed passage for the treatment of failed DCR.

Methods: 60 consecutive patients (35 females and 25) males qualifying the inclusion criteria for repeat DCR, were included in our study along with a patent upper, lower and common canaliculus. Patients less than 16 years \& more than 70 years with acute attack of dacryocystitis, history of nasal or orbital trauma, secondary NLD obstruction, punctal occlusion, canaliculus obstruction and any nasal pathology causing epiphora were excluded. Surgery was performed under local anaesthesia by a single surgeon. Arruga bone trephine of $10 \mathrm{~mm}$ was used in all cases to make an osteum. A circumosteal intra mucosal injection of $0.02 \% \mathrm{MMC}$ at 4 points $(0.1 \mathrm{ml}$ at each point) was given equally at 4 points along the edges of the ostium and 1 point in the anterior remnant of the sac. Syringing with $1 \mathrm{ml}$ of $0.2 \mathrm{mg} / \mathrm{ml} M M C$ was performed in newly formed passage near the bone osteum on the first postoperative day sac in all cases.

Results: The mean age of the patient was 52.45 +- 15.5 ranging from 16 to 68years comprising 35 females and 25 males. Most common presentation was a mucopurulent discharge and primary acquired nasolacrimal duct obstruction was the was the most common indication of surgery. 57 out of 60 patients were symptom free and patent on syringing at the end of follow up period of one year. No wound infection, abnormal nasal bleeding or any noticeable conjunctival and corneal complications were observed during intraoperative, postoperative or during follow up period and 3 patients had failed syringing at the end of one year possibly due to circumosteal fibrous tissue.

Conclusion: Results suggests that our modified technique had safety, reliability, high success rate and can be easily done by most surgeons. 


\section{Introduction}

The aim of dacryocystorhinostomy surgery is to eliminate the fluid and mucus retention within the lacrimal sac by establishing a low resistance drainage pathway between the tear sac and nasal cavity. Dacryocystorhinostomy or DCR is the commonest oculoplasty surgery performed for managing epiphora due to nasolacrimal duct obstruction first described by Totis ${ }^{1}$. The frequency of recurrent epiphora after DCR surgery is reported as $5 \%$ to $17 \%$ in different study series ${ }^{2}$. The reported success rate of the conventional surgery varies between $85 \%$ to $99 \%^{2,3,4}$ but possibility of failure always exists. Surgeon's experience is also attributed to the outcomes as Onerci et al. noted a success rate of $58 \%$ in the inexperienced surgeons' group versus $94 \%$ in the experienced group ${ }^{12}$

Any revision procedure requires a creation of proper osteum and further supplementation with anti-metabolites which become the determinants of successful surgery. Anti-metabolites, like mitomycin-C (MMC), which inhibits circumosteal fibrous tissue growth and scarring, has a role intraoperatively and postoperatively in DCR. It maintains the patency of the osteum and increases the success rate of $\mathrm{DCR}^{13}$. As a result, the repeatDCR procedure, is recommended as highly appropriate revision surgery for failed DCRs, having a high success rate, strengthened by Mitomycin C and creation of a proper osteum.

\section{Aim}

A Prospective study of patients to assess the success rate of repeat DCR surgery by flapless modified Toti's rhinostomy with intraoperative use of Mitomycin $\mathrm{C}$ and syringing on first postoperative day in newly formed passage for the treatment of failed DCR.

\section{Methods}

60 consecutive patients ( 35 females and 25) males qualifying the inclusion criteria for repeat DCR, presenting at the Regional Institute of Ophthalmology, IGIMS, Patna were included in our study between July 2016 to October 2017. Inclusion criteria ensured the enrolment of patients of failed DCR with a positive ROPLAS above the age of 16 years, and a patent upper, lower and common canaliculus.

The exclusion criteria included patients with acute attack of dacryocystitis, history of nasal or orbital trauma, secondary NLD obstruction, punctal occlusion, canaliculus obstruction and any nasal pathology causing epiphora. Patients less than 16 years \& more than 70 years, diabetics, history of bleeding diathesis, hypertension and known coronary artery disease were excluded. Age less than $16 \&$ more than 70 years and ere also excluded from the study.

\section{Surgical Technique}

Surgery was performed under local anaesthesia by a single surgeon in all the cases to minimize the outcome bias of surgical experience. Skin incision was made through the original scar. Intervening scar tissue was excised and identification of the sac was done with the use of Methylene blue followed by dissection and removal of anterior and posterior parts of the sac leaving a remnant around the common internal opening (Fig 1). Arruga bone trephine of $10 \mathrm{~mm}$ was used to make an osteum in lacrimal bone and passage in nasal mucosa so that internal common opening faced the nasal cavity (Fig 2). A circumosteal intra mucosal injection of $0.02 \% \mathrm{MMC}$ at 4 points $(0.1$ $\mathrm{ml}$ at each point) was given equally at 4 points along the edges of the ostium ${ }^{17}$ (Fig 3). and 1 point in the anterior remnant of the sac. The Orbicularis and tendon were repositioned with an absorbable suture with the anterior remnant of the sac taking care that the area around the common internal opening is undamaged and smooth. The skin was then closed with an interrupted nylon sutures. Syringing with $1 \mathrm{ml}$ of $0.2 \mathrm{mg} / \mathrm{ml} \mathrm{MMC}$ was performed in newly formed passage near the bone osteum on the first postoperative day sac in all cases (Fig 4). Post operative regimen included oral and local antibiotics with nasal decongestants for one week. Follow up was scheduled on day1, 
day 7 and thereafter at the end of 1 month, three month, and one year from the day of surgery. Skin sutures were removed after ten days of surgery. Complications such as wound gape, infection, monitoring of the osteum, discharge and epistaxis, if any, were noted in each follow up visits. The success criteria were symptomatic relief from epiphora and a patent nasolacrimal duct upon syringing at the end of follow up period of one year.

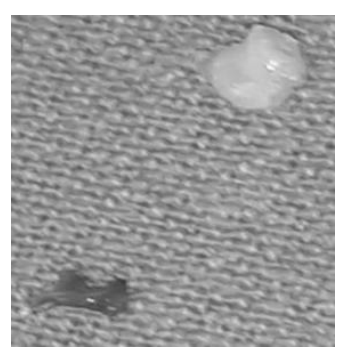

Fig 1 Dissected sac and mucosa

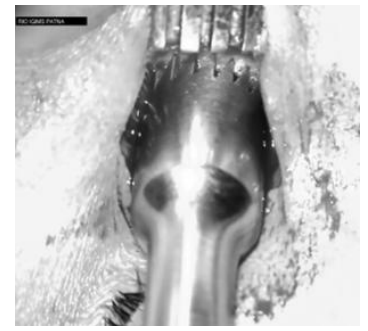

Fig 2 Osteum construction

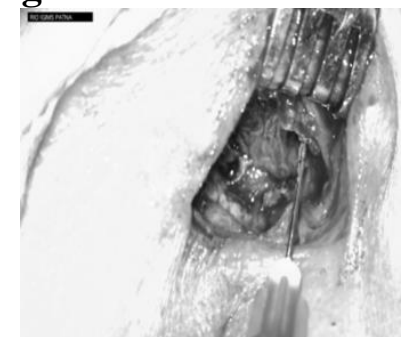

Fig 3 Circumosteal injection

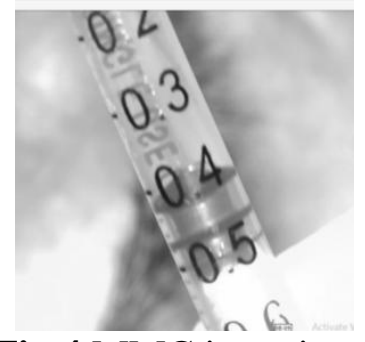

Fig $4 \mathrm{MMC}$ in syringe

\section{Results}

The study group comprised of 35 females and 25 males. The mean age of the patient was $52.45+-$ 15.5 ranging from 16 to 68 years. The most common presentation was a mucopurulent discharge with signs of regurgitation on pressure. Primary Acquired Nasolacrimal duct obstruction was the was the most common indication of surgery. Postoperatively, 57 out of 60 patients were symptom free and patent on syringing at the end of follow up period of one year. Three patients had failed syringing at the end of one year possibly due to circumosteal fibrous tissue growth and scarring. Ten cases had intraoperative bleeding which was controlled effectively and epistaxis was observed in two cases postoperatively which was relieved by nasal packing. No wound infection, abnormal nasal bleeding or any noticeable conjunctival and corneal complications were observed during intra operative, postoperative or during follow up period.

Table 1: Age and Gender distribution(total no. of patients 60 )

\begin{tabular}{|l|c|c|}
\hline Age range of patients & Male & Female \\
\hline $16-20$ & 01 & 00 \\
\hline $21-30$ & 01 & 02 \\
\hline $31-40$ & 02 & 03 \\
\hline $41-50$ & 08 & 07 \\
\hline $51-60$ & 09 & 10 \\
\hline $61-68$ & 04 & 03 \\
\hline Total & 25 & 35 \\
\hline
\end{tabular}

Table 2 Presenting symptoms in total cases

\begin{tabular}{|l|c|}
\hline Symptoms & No. of pt. \\
\hline Watering & 10 \\
\hline Watering with swelling in sac area & 09 \\
\hline Mucopurulent discharge & 19 \\
\hline $\begin{array}{l}\text { Mucopurulent discharge with swelling } \\
\text { over sac }\end{array}$ & 06 \\
\hline Mucopurulent discharge with watering & 12 \\
\hline Encysted mucocoele & 04 \\
\hline Regurgitation test +ve & 56 \\
\hline
\end{tabular}

Table 3 Intraoperative complications

\begin{tabular}{|l|c|}
\hline Complications & $\begin{array}{c}\text { Number of } \\
\text { patients }\end{array}$ \\
\hline $\begin{array}{l}\text { Misdirection and inappropriate nasal } \\
\text { packing }\end{array}$ & 03 \\
\hline Bleeding & 10 \\
\hline Punctum and canalicular laceration & 00 \\
\hline Medial palpebral ligament injury & 05 \\
\hline Non identification of sac & 00 \\
\hline Inadequate osteum abrasion \& conjunctival & 00 \\
\hline $\begin{array}{l}\text { Corneal acerations } \\
\text { lacen }\end{array}$ & 00 \\
\hline
\end{tabular}


Table 4 Post operative complications

\begin{tabular}{|l|c|}
\hline Complications & Number of patients \\
\hline $\begin{array}{l}\text { Corneal abrasion \& conjunctival } \\
\text { lacerations }\end{array}$ & 00 \\
\hline Lid edema & 05 \\
\hline Nasal Bleeding & 02 \\
\hline Suture abscess & 01 \\
\hline Incisional edema & 05 \\
\hline Wound gape & 00 \\
\hline Persistent Epiphora & 03 \\
\hline
\end{tabular}

Table 5 Gender \& Laterality

\begin{tabular}{|l|c|c|}
\hline Eye involved & Male & Female \\
\hline Right Eye & 14 & 16 \\
\hline Left eye & 11 & 19 \\
\hline
\end{tabular}

\section{Discussion}

One of the most frequent causes of failure of DCR is obstructive closure of the osteotomy site ${ }^{(3)}$. If the failed DCR surgery was an E-DCR, it was obviously harder to recreate flaps than for the other failed DCR techniques because of the existence of granulation and fibrotic tissue. They have excessive granulation tissue at the surgical area, especially surrounding the sac and previous flaps. Repeat external DCR surgeries have reported $85 \%$ anatomical success and $78 \%$ both anatomical and functional success ${ }^{[3]}$.

Mitomycin C (MMC) is widely used systemically for the treatment of malignancies, and has gained popularity as topical adjunctive therapy in ocular and adnexal surgeries over the past 2 decades. In ophthalmic medicine, it is principally used to inhibit the wound healing response and reduce scarring of surgically fashioned ostia. Hence, it has been used as adjunctive therapy in various ocular surgeries, such as glaucoma filtering surgeries, dacryocystorhinostomy, corneal refractive surgery and surgeries for ocular cicatrisation $^{(8)}$. Significant changes in the nasal mucosa have been seen with topical and circumosteal use of MMC which were more marked in the circumosteal group. These limited changes of the nasal mucosa help in enhancing the success of dacryocystorhinostomy by possibly preventing cicatricial changes of the ostium ${ }^{18}$. In a study of intra operative MMC with DCR, Kao et $\mathrm{al}^{15}$ found that the osteotomy site was significantly larger in the mitomycin group than the control group. Ugurbas et $\mathrm{aI}^{18}$ studied the histopathologic effects of MMC on transnasal DCR by soaking the osteotomy site in MMC $0.5 \mathrm{mg} / \mathrm{mL}$ for 2.5 minutes. The histopathologic evidence of attenuated epithelium and looser, hypocellular, subepithelial connective tissue in the MMC specimens suggests the efficacy of MMC application as seen on light and electron microscopy.

Failure occurs due to inadequate size of ostium, blockage of osteotomy due to granulation tissue, scarring and formation of adhesions and synechiae in the nasal cavity ${ }^{[3]}$. Using the Arruga's bone trephine (size $10 \mathrm{~mm}$ ) makes it easier to fashion an adequate osteotomy size of $10 \mathrm{~mm}$ with a smooth margin. ${ }^{3}$ In a study, Onerci et al. noted a lower success rate in the inexperienced surgeons' group as compared to the experienced group doing Ext DCR. ${ }^{12}$ The most common causes of failures among the inexperienced group are inadequate lacrimal sac marsupialization, inadequate osteotomy, and improper localization of $\mathrm{sac}^{12}$. Since the flapless modified Toti's procedure done in our study does not require any flap and lacrimal sac marsupialisation, but only a stump close to the common internal opening, it becomes easier to perform for inexperienced surgeons and attain a better outcome.

Mitomycin C (MMC), an antiproliferative agent extracted from "Steptomycescaespitosus" has properties of suppressing DNA, cellular RNA and protein synthesis. Thus, if we can inhibit fibrous tissue growth and scarring by applying anti proliferative agents over the osteum and nearby the site, the failure rate may be decreased. Because of the known anti fibroblastic properties of Mitomycin C, it was used in our study. Mitomycin C is effective even if applied $0.2 \mathrm{mg} / \mathrm{ml}$ for 30 seconds ${ }^{(8,9)}$. A single topical application has measurable effect on cell proliferation and cellular morphology for up to 36 hours. EXT-DCR, when compared with EESC-DCR, appears to give a higher, although not statistically significant, primary success rate $^{(7,8)}$. Our success rate is 
comparable with that of primary operated DCRs. In previous failed E-DCRs, Emine Akcay. Nilay Yuksel. Umut Ozen detected excessive granulation tissue at the operation site as the main reason for failure ${ }^{(7)}$. Of the three cases of epiphora in our study, one was due to entropion and two were due to blocked ostia confirmed by endoscopy.

\section{Conclusion}

Our result was $95.12 \%$ success. Under H0, i.e. $\mathrm{P} 1=\mathrm{P} 2$ the value of the test statistics $\mathrm{Z}$ was calculated and found to be more than 2 , which means $\mathrm{HO}$ is to be rejected in favour of alternative, $\mathrm{p} 1>\mathrm{p} 2$ at level of significance 0.05 ( $\mathrm{p}$ value $<$ 0.05 ). Statistically our result was superior to the earlier result. Of the three cases of epiphora, one was due to entropion and two were due to failure of the surgical process which may be attributed to the excessive bleeding and later on formation of excessive granulation tissue leading to the blockage of the osteum in due course.

So, it may be concluded that management by modification of Toti's procedure ${ }^{1}$ as flapless modified Toti's rhinostomy with adjunctive use of Mitomycin C (MMC) is a safe, reliable and useful procedure in cases of failed external DCR which can be easily done by most surgeons.

\section{References}

1. Toti A (1904) Nuovo metodoconservatore di curaradicaledellesuporazionichroniche del saccolacrimale. Clin Mod Firenze 10:385-389.

2. Rabina G, Golan S, Neudorfer M, Leibovitch I. External Dacryocystorhinostomy: Characteristics and Surgical Outcomes in Patients with and without Previous Dacryocystitis. J Ophthalmol 2013. 2013:287524

3. Ali, Mohammad Javed et al. "Dacryocystorhinostomy ostium: parameters to evaluate and DCR ostium scoring” Clinical ophthalmology
(Auckland, N.Z.) vol. 8 2491-9. 9 Dec. 2014

4. Shams PN, Chen PG, Wormald PJ, et al. Management of functional epiphora in patients with an anatomically patent dacryocystorhinostomy. JAMA Ophthalmol 2014; 132(9):1127

5. Korkut AY, Teker AM, Ozsutcu M, Askiner O, Gedikli O. A comparison of endonasal with external dacryocystorhinostomy in revision cases. Eur Arch Otorhinolaryngol.2011; 268:377-81.

6. Ari S, Ku“rs at Cingu“ A, Sahin A, Gu“n $\mathrm{R}$, Kinis, V,Cac, a I. Outcomes of revision external dacryocystorhinostomy and nasal intubation by bicanalicular silicone tubing under endonasal endoscopic guidance. Int J Ophthalmol. 2012; 5(2):238-41.

7. Emine Akcay. Nilay Yuksel . Umut Ozen, Revision External Dacryocystorhinostomy Results After a Failed Dacryocystorhinostomy Surgery. OphthalmolTher (2016) 5:75-805.

8. Abraham LM1, Selva D, Casson R, Leibovitch I.05:1106-13. Mitomycin: clinical applications in ophthalmic practice. Drugs. 2006; 66(3):321-40.

9. Cheng HC, Sung-Huel T, Ping-Lin K, et al. Low-dose intraoperative mitomycin $\mathrm{C}$ as chemoadjuvant for pterygium surgery. Cornea 2001; 20:24-9.

10. El-Guindy A, Dorgham A, Ghoraba M. Endoscopic revision surgery for recurrent epiphora occurring after external dacryocystorhinostomy. Ann Otol Rhinol Laryngol. 2000;109(4):425-30.

11. Hartikainen J, Grenman R, Puukka P, Seppa H. Prospective randomized comparison of endonasal endoscopic dacryocystorhinostomy and external dacryocystorhinostomy. Ophthalmology 1998;105:1106-1113.

12. Onerci M, Orhan M, Ogretmenoglu O, Irkeç M. Long-term results and reasons for failure of intranasal endoscopic 
dacryocystorhinostomy. Acta

Otolaryngol2000;120:319-22.

13. Iqbal A, Khan O. External dacryocystorhinostomy with and without intraoperative mitomycin-C application in adults. Ophthalmology. 2012;10(3):262-5.

14. Liao LS, Kao SCS, Tseng JHS, Chen MS, Hou PK. Results of intraoperative mitomycin $\mathrm{C}$ application in dacryocystorhinostomy. Br J Ophthalmol. 2000;84:903-6.

15. Kao SC, Liao CL, Tseng JH, Chen MS, Hou PK. Dacryocystorhinostomy with intraoperative mitomycin C. Ophthalmology 1997;104:86-91.

16. Tsai CC, Kau HC, Kau SC, Hsu WM, Liu JH. Efficacy of probing the nasolacrimal duct with adjunctive mitomycin $\mathrm{C}$ for epiphora in adults. Ophthalmology. 2002;109(1):172-4.

17. Kamal, Saurabh M.D.; Ali, Mohammad Javed M.D., F.R.C.S.; Naik, Milind N. M.D.Circumostial Injection of Mitomycin $\mathrm{C}$ : Implications in Dacryocystorhinostomy: Efficacy, Safety Profile, and Outcomes.Ophthalmic Plastic and Reconstructive Surgery: March/April 2014 - Volume 30 - Issue 2 - p 187-190

18. Ali, Mohammad Javed F.R.C.S.; Baig, Farhana M.D., D.N.B. ${ }^{\dagger}$; Lakshman, Mekala Ph.D."; Naik, Milind N. M.D. Electron Microscopic Features of Nasal Mucosa Treated with Topical and Circumostial Injection of Mitomycin C: Implications in Dacryocystorhinostomy. Ophthalmic Plastic and Reconstructive Surgery: March/April 2015 - Volume 31 Issue 2 - p 103-107

19. Ugurbas SH, Zilelioglu G, Sargon MF, Anadolu Y, Akiner M, Aktürk T. Histopathologic effects of mitomycin-C on endoscopic transnasal dacryocystorhinostomy. Ophthalmic Surg Lasers 1997;28:300-4. 